\title{
Dilution in New ZeAland: The EFFECTS OF THE TARNISHMENT LIMB of Dilution on FreE SPEECH
}

\author{
Alexandra Sims*
}

Calls have been made to introduce trade mark dilution into New Zealand's trade mark legislation. Currently trade mark protection is limited to the same or similar goods or services to those over which the trade mark is registered, and within this class only certain uses of that trade mark are protected. The positive associations - the selling power - of famous trade marks is such that their use on dissimilar goods or services can make those goods or services more attractive to consumers. Trade mark dilution recognises that such unauthorised use will weaken the famous trade mark's selling power and proscribes such use. Trade mark dilution, however, goes further and removes the distinction currently made between different uses of a trade mark. Infringement occurs if unauthorised use of the trade mark damages the positive associations the trade mark invokes. Unless exceptions are made to the latter aspect of trade mark dilution, the impact of trade mark dilution upon free speech will be significant.

$I$

\section{INTRODUCTION}

The Trade Marks Act 1953 provides a trade mark with a narrow field of protection. A "trade mark" is able to be used in a number of ways which will not result in trade mark infringement regardless of the damage caused to it. ${ }^{1}$ If the concept of trade mark dilution becomes part of New Zealand's trade mark law, the scope of protection provided to trade marks will change significantly. ${ }^{2}$ Trade mark infringement will occur if the use of a sign

Lecturer, School of Business and Economics, University of Auckland.

1 Infringement occurs under s 8 of the Trade Mark Act 1953 (this article does not deal with Part B trade marks) when a sign identical or similar to a registered trade mark is used. Therefore, this article will use the term "sign" to refer to the second user's use of a trade mark.

2 The term "dilution" will be used to refer to trade mark dilution and anti-dilution. 
causes damage to a trade mark, unless the use comes within an exception. Dilution recognises two types of damage: "blurring" and "tarnishment". Blurring arises when the unauthorised use of a sign on other goods reduces the recognition factor of the trade mark. Tarnishment occurs when a sign is used in a context which causes people to think less of that which the trade mark signifies, whether it be goods, services or the trade mark owner itself. ${ }^{3}$

In 1991, the Ministry of Commerce, as it then was, looked at the introduction of a dilution provision along the lines of what the United Kingdom subsequently adopted in the Trade Marks Act 1994 (UK). The Ministry rejected including the dilution provision on the basis: (1) that it would do little to broaden a trade mark owner's rights beyond that already provided by passing off and the Fair Trading Act 1986; and (2) that it would introduce uncertainty into the law. ${ }^{4}$

Nearly a decade has passed since the Ministry declined to introduce dilution into New Zealand's trade mark legislation. Australia too provides no protection against dilution and Ricketson, in an attempt to remedy this gap in protection, put forward a proposal in the form of the imaginary Trade Marks Amendment (Anti-Dilution Protection) Act 1999 (Cth) ("the Australian Proposal"). ${ }^{5}$ In New Zealand, Glengarry argued that New Zealand should adopt the Australian Proposal in its entirety. ${ }^{6}$ Neither Ricketson nor Glengarry fully addressed tarnishment and its effects on free speech; therefore, this article seeks to bring some balance to the debate by addressing the tarnishment limb of dilution. The blurring limb of dilution is beyond the scope of this article.

Part II of this article discusses the protection of trade marks under the Trade Marks Act 1953 and provides examples of the use of signs that would not result in infringement under that Act ("the non-infringing uses"). Part III explains the theory of trade mark dilution and its effects on the non-infringing uses. Part IV examines the Australian Proposal and its effect upon the non-infringing uses. Part V discusses the justifications for increasing property rights

3 References to goods where applicable will also refer to services.

4 Ministry of Commerce Reform of the Trade Marks Act 1953: Proposed Recommendations (Wellington, 1991) 29.

5 Ricketson "Dilution and Confusion - the Basis of Trade Mark Infringement or the new Australian Trade Mark Anti-dilution Law 1999" in C E F Rickett and G W Austin (eds) International Intellectual Property and the Common Law World (Hart Publishing, Oxford, 2000) 155 - 157.

6 John Glengarry "An Anti-Dilution Trade Mark Law for New Zealand?" (2000) 6 NZBLQ 258, 267. 
afforded to trade marks, and the consequences of granting greater property rights on free speech. Finally, Part VI outlines the approach of the United States to tarnishment.

\section{THE PROTECTION OF TRADE MARKS UNDER THE TRADE MARKS ACT 1953}

The Trade Marks Act 1953 ("the Act") governs trade mark law in New Zealand, this article is concerned only with registered trade marks. ${ }^{8}$ However, the functions that trade marks are seen as performing control the rights granted to the trade mark owner. The origins of trade marks are to be found in deceit. ${ }^{9}$ The consumer is entitled to rely on a trade mark, if the consumer is misled into purchasing a good by another trader imitating a trade mark, the law allows the trade mark owner to prevent the deception from continuing to occur. The trade mark owner is thus protected under the guise of consumer protection, ${ }^{10}$ that is trade mark law prevents confusion or deception from occurring. Trade marks, therefore, serve two functions, they act: (1) as a badge of origin, indicating the origin or source of the goods; and (2) as a badge of quality. ${ }^{11}$ The Act incorporates both these functions.

\section{A The Exclusive Rights of Trade Mark Owners under the Trade Marks Act 1953}

Section $8(1)$ provides the trade mark owner with the exclusive right to the use of the trade mark in relation to those goods over which the trade mark is registered. The term "in relation to goods" requires goods to be offered under that trade mark, if no goods are being offered there is no relevant use of the trade mark, thus no infringement. ${ }^{12}$ Section $8(1 \mathrm{~A})$ further

7 The writer is acutely aware that New Zealand is not an outpost of the United States and trade mark law in the two jurisdictions is different. However, with the Australian Proposal drawing as it does heavily upon United States legislation, it has been necessary to look at the decisions of the courts in that jurisdiction.

8 Trade marks that are registered on the trade mark register: Trade Marks Act 1953, s 2.

9 Schechter The Historical Foundations of the Law Relating to Trade-Marks (Columbia University Press, New York, 1925) $141-143$.

10 Ricketson, above n 5, 128 described this transformation as the genius of the common law.

11 Villa Maria Wines Ltd v Montana Wines Ltd [1984] 2 NZLR 422, 427 (CA) [Villa Maria] citing with approval Re Powell's Trade Mark [1893] 2 Ch 388, 403 - 404 (CA).

12 Daiquiri Rum Trade Mark (1966) RPC 582 (HC) (The use of the trade mark in trade literature and on the side on vans was not use in relation to goods, as the goods were not available in England due to the Second World War). See also A Brown and A Grant The Law of Intellectual Property in New Zealand (Butterworths, Wellington, 1989) para 2.6; T Blanco White and R Jacob Kerly's Law of Trade Marks and Trade Names (12 ed, Sweet \& Maxwell, London, 1986) para 2-06. 
restricts the trade mark owner's right. It provides that infringement occurs when another person uses in the course of trade: (1) an identical sign over identical goods; ${ }^{13}$ (2) an identical sign over similar goods; ${ }^{14}$ or (3) a similar sign over identical or similar goods. ${ }^{15}$ A trade mark owner is therefore powerless, under trade mark law, to prevent its trade mark being used in relation to dissimilar goods.

Moreover, section $8(1 \mathrm{~A})(\mathrm{d})$ provides that in order for infringement to occur the sign must be used as a trade mark. ${ }^{16}$ "Use as a trade mark" means that the sign is being used to indicate the origin of the goods. ${ }^{17}$ If people seeing the sign realise that the trade mark owner has no connection with the goods, the sign will not have been used as a trade mark and thus infringement can not occur. However, not all is lost for a trade mark owner if they are unable to show use as a trade mark. Protection is also offered in the form of $8(1 \mathrm{~A})(\mathrm{e})$ which provides that trade mark infringement will occur if a sign is used:

$[u]$ pon goods or in physical relation to goods or in an ... advertisement issued to the public relating to goods, as importing a reference to some person having the right ... as proprietor ... to use the trade mark or to goods which such a person is connected in the course of trade...

13 Trade Marks Act 1953, s 8(1A)(a).

14 Trade Marks Act 1953, s 8(1A)(b).

15 Trade Marks Act 1953, s 8(1A)(c).

16 Both ss $8(1 \mathrm{~A})(\mathrm{b})$ - (c) require that the use of the sign is "likely to deceive or cause confusion", however, for the purposes of this article it is conceded that identical signs are being used over identical goods.

17 Villa Maria, above n 11, 430. A trade mark was defined under s 2(1) of the Trade Marks Act 1953 as "a mark used or proposed to be used in relation to goods for the purpose of indicating, or so as to indicate, a connection in the course of trade between the goods and some person having the right either as a proprietor or as registered user to the mark, whether with or without any indication of the identity of that person ..." The definition of a trade mark has undergone changes in the intervening years, s 4(1) Trade Marks Amendment Act 1999 providing the latest amendment. A trade mark is now defined as "mean[ing] a sign - (i) Capable of being represented graphically; and (ii) Capable of distinguishing those goods or services of one person from those of another." The latest definition mirrors that of the Trade Marks Act 1994 (UK), s 1 "a trade mark means any sign capable of being represented graphically which is capable of distinguishing goods ... of one undertaking from those of other undertakings." However, the nature of a trade mark as representing origin remains unchanged: British Telecommunications Plc v One in a Million Ltd [1998] 4 All ER 476, 499 (CA) [One in a Million]; Wagamama Ltd v City Centre Restaurants Plc [1995] FSR 713, 730-731 (HC); see also Amanda Michaels A Practical Guide to Trade Mark Law (2 ed, Sweet \& Maxw ell, London, 1996). 
This provision was introduced in the United Kingdom to prevent comparative advertising, ${ }^{18}$ with New Zealand in turn enacting an identical provision. ${ }^{19}$ It is a truism that trade mark registration in New Zealand does not extend trade mark owners' rights beyond that provided in section 8 of the Act. ${ }^{20}$ But, the actual extent of the protection depends on the meaning of section $8(1 \mathrm{~A})(\mathrm{e})$. Are all uses of a sign on goods identical or similar to those goods over which the trade mark is registered that refer in some way to the trade mark owner or its goods caught by this provision? "Anti-competitive" behaviour is beyond the scope of this article, ${ }^{21}$ so to is comparative advertising. This article is concerned with the effect of increased protection for trade marks on freedom of speech. Due to the paucity of New Zealand trade mark cases in this area, it is necessary to refer to examples of the use of signs from other jurisdictions, which the writer believes would not result in trade mark infringement under the Act. Whether the "non-infringing uses" remain non-infringing under the Australian Proposal is examined in Part IV.

\section{B Uses of Trade Marks Beyond the Con trol of the Trade Mark O wner}

\section{Descriptive use}

In the examples of uses of signs that follow, there is no use of a sign as a trade mark. The users of the signs were not purporting that their "goods" (if indeed there were any) were the trade mark owner's goods, or that the trade mark owner had any connection with the goods. Therefore, no confusion was caused, although, in all but the first "non-infringing use" direct reference was made to the trade mark owner or its goods.

18 Trade Marks (Amendment) Act 1937 (UK) which was consolidated into the Trade Marks Act 1938 (UK), s 4(1)(b) and see Bismag Ltd v Amblins (Chemist) Ltd [1940] Ch 667, 676 - 681 (CA) per Greene MR.

19 Patents, Designs and Trade Marks Amendment Act 1939 which was consolidated into the Trade Marks Act 1953, s 8(1)(b), and see Villa Maria, above n 11, 428. The Trade Marks Amendment Act 1987 has since amended the provision's number to $\mathrm{s} 8(1 \mathrm{~A})(\mathrm{e})$.

20 Greater protection is given to "well-known" trade marks which can be defensively registered under s 36 of the Trade Marks Act 1953, as the protection is not limited to identical or similar goods. Again trade mark use is necessary.

21 See generally, P Sumpter "Sports Law and Intellectual Property: How Watertight is an America's Cup" (1999) 2 NZIPJ 109. 
(a) Use of common English words in literary titles

The Court of Appeal in Villa Maria Wines Ltd v Montana Wines Ltd ${ }^{22}$ believed that section $8(1 \mathrm{~A})(\mathrm{e})$ must deal with another type of use of a sign that did not indicate the origin of the alleged infringer's goods. The defendant in an advertisement had placed a bottle of its wine alongside a bottle of the plaintiff's wine, with the trade marks on both bottles visible. The advertisement praised both wines and suggested they were of equal quality. The court approved the meaning attributed to the provision by the majority of the English Court of Appeal in Bismag Ltd v Amblins (Chemist) Ltd..$^{23}$ Infringement would occur if the sign was used in a trade mark sense, if there was no such requirement, the mere use of a word which happened to be a trade mark would result in infringement. ${ }^{24}$ Neither court actually defined what trade mark sense meant. However, Greene MR in Bismag Ltd v Amblins (Chemists) Ltd did observe that use in a trade mark sense was not dependant on confusion or deception. ${ }^{25}$ "[The provision] confers upon the proprietor a novel type of monopoly for which no consideration is given to the public ... beyond fees payable on registration." 26 However, the monopoly was not absolute, Greene MR in obiter, provided an example of a shoe manufacturer who had registered CROCODILE over shoes made of crocodile leather. Another shoe manufacturer would be able to describe its shoes as "made of crocodile skin" but not "as good as the "Crocodile" brand shoes". The former was descriptive use, which the provision did not catch, ${ }^{27}$ whereas the latter was use in a trade mark sense. ${ }^{28}$

Yet, despite Greene MR's clear explanation of the ability to use a sign descriptively, subsequent courts have misapplied the prohibition against use in a trade mark sense. In Mothercare UK Ltd v Penguin Books Ltd, ${ }^{29}$ Mothercare, a large corporation, sold an extensive

22 Villa Maria, above n 11.

23 Bismag Ltd v Amblins (Chemists) Ltd [1940] Ch 667 (CA) [Bismag].

24 Villa Maria, above n 11, 430; Bismag, above n 23, 682 per Greene MR.

25 Bismag, above n 23, 677 per Greene MR.

26 Bismag, above n 23, 677 - 678 per Greene MR.

27 Trade Marks Act 1953, s 12(b) also provides an express defence for descriptive use, however, the use cannot be "a description that would be likely to be taken as importing any such reference as is mentioned in $[\mathrm{s} 8(1 \mathrm{~A})(\mathrm{e})] . "$

28 Bismag, above n 23, 682-683 per Greene MR.

29 Mothercare UK Ltd v Penguin Books Ltd [1988] RPC 113 (CA) [Mothercare]. 
range of products for babies and expectant mothers, including non-controversial books on child rearing. Mothercare sought an injunction to prevent the publication of a book entitled "Mother Care/Other Care", alleging the book title infringed its trade mark MOTHERCARE (registered in class 16). The book controversially argued the belief that pre-school aged children did best if they were brought up by their mothers was of recent origin and was unsupported by evidence. The American authors of the book had no knowledge of Mothercare the company and the book made no reference to Mothercare. The High Court granted an interlocutory injunction for trade mark infringement on the basis that people seeing the book would automatically think of Mothercare the company because it was a household name. ${ }^{30}$

The English Court of Appeal, however, was unanimous in finding no infringement had occurred. Dillion LJ found that it was such a good descriptive title it was difficult to think of an equally good alternative. ${ }^{31}$ The registration of a descriptive word or words as trade marks did not deny the ability of others to use those words descriptively. ${ }^{32}$ Had the plaintiff been successful in preventing the defendant from using "Mother Care", Parliament would have granted the plaintiff a commercial copyright in those words. ${ }^{33}$ Dillion LJ perceptively observed that the issue was "how far, because of its name, Mothercare is entitled to restrain the expression of controversial views by others." ${ }^{34}$

(b) Direct reference to the trade mark owner in literary titles

How far does the refusal of Dillon LJ to allow trade mark law to be utilised by Mothercare to restrain the views of others extend? Green MR's example of the use of "Crocodile" in Bismag Ltd $v$ Amblins (Chemists) Ltd provided Mothercare with a warning that it would pay the price of adopting a descriptive trade mark. But does this exception apply to section $8(1 \mathrm{~A})(\mathrm{e})$ when the trade mark in question is not descriptive or capable of being used descriptively - where the trade mark consists of an invented word? In Bismag Ltd $v$ Amblins (Chemists) Ltd Greene MR had stated that because the trade mark BISURATED had no descriptive significance, it could

30 Mothercare UK Ltd v Penguin Books Ltd (19 May 1987) unreported, High Court, Chancery Division per Falconer J.

31 Mothercare, above n 29, 116 per Dillon LJ.

32 Mothercare, above n 29, 119 per Dillon LJ.

33 Mothercare, above n 29, 128 per Bingham MR.

34 Mothercare, above n 29, 114 per Dillon LJ. 
not be used descriptively. ${ }^{35}$ Thus a rock group who had trade marked its name WET WET WET in class 16 would appear to be able to prevent the publication of a biography of a book entitled: "A Sweet Little Mystery - Wet Wet Wet - The Inside Story". ${ }^{36}$ Is the monopoly granted to a trade mark owner under section $8(1 \mathrm{~A})(\mathrm{e})$ wide enough to catch such use?

Despite not defining use in a trade mark sense, ${ }^{37}$ the Court of Appeal in Villa Maria Wines Ltd $v$ Montana Wines Ltd did find that the sign had been used in a trade mark sense. The sign s had been used to advertise the defendant's own wine, "to get a benefit from the reputation which has accrued to [the plaintiff's] wines." 38 Greene MR in Bismag Ltd v Amblins (Chemists) Ltd similarly stated that the purpose of the use was to describe the virtues of the defendant's goods. ${ }^{39}$

The mere use of a sign in advertising, therefore, was not sufficient in Villa Maria Wines Ltd $v$ Montana Wines Ltd or Bismag Ltd v Amblins (Chemists) Ltd to cause infringement. It was the purpose of the use which determined whether the sign had been used in a trade mark sense. ${ }^{40}$ Indeed Plow man J in Pompadour Laboratories Ltd $v$ Stanley Frazer ${ }^{41}$ made it clear that not every use of a sign which referred to the trade mark owner was use in a trade mark sense. Pompadour Laboratories Ltd, claimed that its trade mark POMPADOUR had been infringed by the defendant advertising: "Frazer Chemicals have manufactured hair lacquer for Pompadour Laboratories Ltd for several years." Plowman J found that "Pompadour Laboratories Ltd" was not use in a trade mark sense, the reference was to the plaintiff's name

35 Bismag, above n 23, 675 per Greene MR.

36 Bravado Merchandising Ltd v Mainstream Publishing Ltd [1996] FSR 205 (HC) [Bravado Merchandising].

37 Villa Maria, above n 11, 430. The court simply stated that the "innocent" use of a sign would not result in trade mark infringement, but it did not define was innocent meant.

38 Villa Maria, above n 11, 430.

39 Bismag, above n 23, 675 per Greene MR.

40 See also British Northrop Ltd v Texteam Blackburn [1974] RPC 57, 78 (HC) where Megarry J stated that it was "difficult to see what purpose there is in the use of the [the sign] ... unless it is to commend the defendant's goods by reference to the plaintiff's trade mark." Contrast Bravado Merchandising, above n 36, 214 where Lord McCluskey (obiter) stated that if "the Beatles" was registered as a trade mark, a book entitled "The Beatles - the Golden Years" - there could be no other use of "the Beatles" except in a trade mark sense.

41 Pompadour Laboratories Ltd v Stanley Frazes (1965) RPC 7 (HC) [Pompadour]. 
not the trade mark. ${ }^{42}$ The Court of Appeal in Villa Maria Wines Ltd $v$ Montana Wines Ltd approved Plowman J's interpretation of use in a trade mark sense. ${ }^{43}$

The construction of section $8(1 \mathrm{~A})(\mathrm{e})$ in the context of comparative advertising was more recently the subject of discussion in the interlocutory decision of Elias J (as she then was) in $P C$ Direct Ltd $v$ Best Buy Ltd. ${ }^{44}$ The defendant in the course of comparing its goods with the plaintiff's goods had made disparaging comments about the latter's goods. Elias J acknowledged that the purpose of section $8(1 \mathrm{~A})(\mathrm{e})$ was to protect the trade mark owner against appropriation of its reputation, and it was difficult to see how disparagement was caught section $8(1 \mathrm{~A})(\mathrm{e})$. However, her honour stated that it was implicit that "any such disparagement is an appropriation of reputation to establish a benchmark from which the competitor claims betterment." 45 Thus, the defendant in appropriating the plaintiff's reputation to commend the defendant's goods (albeit indirectly) was caught by section $8(1 \mathrm{~A})(\mathrm{e}) .{ }^{46}$

In summary, section $8(1 \mathrm{~A})(\mathrm{e})$ does not go so far as to make any reference to a trade mark owner an infringement. Use in a trade mark sense is limited by the quality function - in order to infringe under section $8(1 \mathrm{~A})(\mathrm{e})$ a sign must be used commend goods. The descriptive use of signs in literary titles to describe the subject matter of the book (where the trade mark is registered in class 16) will not result in trade mark infringement. ${ }^{47}$

42 Pompadour, above n 41, 12.

43 Villa Maria, above n 11, 430; Pompadour, above n 41, was described as one of the cases that favoured the Bismag view, and that the discussion of use in a trade mark sense in Pompadour was "uncritical".

44 PC Direct Ltd v Best Buy Ltd [1997] 2 NZLR 723 (HC) [PC Direct]. The importance of PC Direct on the issue of comparative advertising lies in the treatment of an amendment made to $s$ 9(2) of the Trade Marks Act 1953 in the form of s 4 of the Trade Marks Amendment Act 1994. Prior to the 1994 amendment, and at the time Villa Maria, above n 22, was decided, there was an express defence in the form of $s 9(2)$ for part B marks if the use of the trade mark was not "likely to deceive or cause confusion". Elias J in PC Direct at 732, made it clear that the amended s 9(2) removed this defence when an identical trade mark was used over identical goods - infringement could occur, despite no one being deceived or confused.

45 PC Direct, above n 44, 729 per Elias J.

46 However, Elias J refused to grant an injunction despite infringement being found due to s 14 of the New Zealand Bill of Rights 1990, see below n 126 - 129 and accompanying text.

47 So long, of course, as the sign does not cause confusion. 


\section{(c) Complaint web sites}

Another descriptive non-infringing use of a sign occurs on complaint web sites. People, disgruntled with the goods, or lack of service, by a company, vent their complaints and encourage others to do likewise. Signs are used on the web sites to identify the subject matter of the complaint, but it is made clear that the web sites are unauthorised. For instance, in Bally Total Fitness Holding Corp $v$ Faber $^{48}$ the plaintiff's trade mark BALLY was used with the word "sucks" printed across it. This seemingly innocuous practice - after all, people should be entitled to discuss the legitimate shortcomings of companies engaged in providing goods to customers - has raised the ire of many a trade mark owner in the United States. ${ }^{49}$ However, all the "alleged offender" is doing is using the sign to identify the subject matter of the web site. Moreover, it is difficult to see how the use of a sign on a complaint web site can result in trade mark infringement. The trade mark must satisfy the requirement that the sign be used in relation to goods in New Zealand, if no goods were being sold under that sign, trade mark infringement cannot occur. ${ }^{50}$

\section{Satire and parody}

Trade mark owners have recognised the hold that trade marks have on popular culture. ${ }^{51}$ For example, Mattel, the trade mark owner of BARBIE, promoted an art exhibition entitled "Art, Design, and Barbie: The Cultural Evolution of a Cultural Icon". 52 Therefore, it is hardly surprising that BARBIE itself was satirized, as trade marks "have become a natural target of

48 Bally Total Fitness Holding Corp v Faber 29 F Supp 2d 1161 (CD Cal) [Bally]. Similar web pages can be found at $<$ http:www.compupix.com/ballysucks $>$.

49 See for example, Ronald Lopez "Corporate Strategies for Addressing Internet Complaint Sites" $<$ http://www.thelenreid.com/articles/article/art_49_idx.htm> (last accessed 10 November 2000); "Web Wars: Companies Get Tough on Rouges Studios and Fortune 500 Firms Target Unauthorised Internet Sites that Feature Their Products. Crackdown Affects Fans as well as Foes" Los Angles Times, Los Angeles, United States of America, 12 November 1996, where Gateway 2000 obtained a restraining order to prevent a former employee from continuing to use Gatew ay 2000's registered trade marks on his web site. The former employee "trashed" Gateway 2000 by including a list containing the top ten reasons why not to buy one of the company's computers.

50 See above $\mathrm{n} 12$

51 See, for example, LL Bean Inc v Drake Publishers Inc (1987) 811 F 2d 26, 34 (1 st Cir) [LL Bean].

52 See Steven M Cordero "Cocaine-Cola, the Velvet Elvis, and Anti-Barbie: Defending the Trademark and Publicity Rights to Cultural Icons" (1998) 8 Fordham IP Media \& Ent Law J 599, 654. 
satirists who seek to comment on this integral part of the national culture". ${ }^{53}$ In Mattel Inc $v$ $M C A$ Records $I n c^{54}$ the satire of BARBIE occurred in a song sold as both a single and as part of a compact disk entitled "Barbie Girl". The lyrics included "I'm a Barbie Girl ... life in plastic ... it's fantastic ... you can brush my hair ... undress me anywhere ... I'm a blond bimbo girl ... in a fantasy world." 55

The satire of BARBIE should not result in trade mark infringement under the Act, it is submitted, because BARBIE was not being used: (1) as a trade mark; or (2) in a trade mark sense. In relation to (1) the pop group was not attempting to deceive the public into thinking the goods came from, or were endorsed by Mattel, thus inducing the public on false pretences into purchasing its goods. ${ }^{56}$ The pop group was simply commenting on both BARBIE, and society in general. A third form of comment can occur when the trade mark owner itself is the target of the satire or parody. Therefore, if the satirist or parodist avoids confusing the public about the origin of the product or that the trade mark owner has authorised the satire or parody the satirist or parodist will not be using the sign as a trade mark. With (2), following Pompadour Laboratories Ltd $v$ Stanley Frazer the satire or parody of a trade mark owner which involved the use of a trade mark because the trade mark owner's name was comprised of a trade mark would not result in trade mark infringement. However in Mattel Inc $v$ MCA Records Inc the satire was not of the trade mark owner itself, instead it was of the trade mark owner's goods. But, as we saw with both Villa Maria Wines Ltd v Montana Wines Ltd and Bismag Ltd $v$ Amblins (Chemists) Ltd in order for the use to be use in a trade mark sense, the sign must

53 Dorsen "Satiric Appropriation and the Law of Libel, Trademark and Copyright: Remedies without Wrongs" (1986) 65 BUL Rev 923, 939. See also "You Oughta be in Pictures" Beverage World, United States of America, April 1990, 23 (trade mark owners pay large sums for their trade marks to appear in movies and television shows, the fee increases with the prominence of the trade mark in the work).

54 Mattel Inc v MCA Records Inc (1998) 28 F Supp 2d 1120 (CD Cal) [Mattel].

55 Aqua "Barbie Girl" (MCA Records, 1997) quoted by Cordero, above n 52, 599.

56 Michael Spence "Intellectual Property and the Problem of Parody" (1998) 114 LQR 594, 598. See generally where the argument has succeeded in relation to passing off: Miss World (Jersey) Ltd v James Street Productions Ltd (1981) FSR 309 (CA) (the promoters of "Miss World" were unable to prevent a film entitled "Miss Alternative World" which was clearly ridiculing "Miss World") and C Wadlow The Law of Passing Off(2 ed, Sweet \& Maxwell, London, 1995) para 6.48. 
be used to commend the defendant's goods. There is no suggestion in Mattel Inc $v$ MCA Records Inc of the sign being used to commend the quality of the goods. ${ }^{57}$

Because the satirist or parodist is not provided with an express defence under trade mark law, both flirt with danger. Trade mark infringement will occur, if the public does not recognise the use of the sign as being a satire or parody, and the sign is used over goods identical or similar to those over which the trade mark is registered. ${ }^{58}$

A more typical example of the use of a sign in parody occurred in Anheuser-Busch Inc $v$ Balducci Publications ${ }^{59}$ where the defendant was commenting on the effects of oil spills on the environment. The parody occurred in a humour magazine in a mock advertisement. MICHELOB DRY, ONE TASTE AND YOU'LL DRINK IT DRY and the slogan "somebody still cares about quality" were altered to "Michelob Oily", "one taste and you'll drink it oily" and "thank goodness someone still cares about quality (of life)". Other distortions of the plaintiff's trade marks included an eagle device dripping with oil. ${ }^{60}$ These uses of the signs would be beyond the scope of the Act, as goods were not sold under the signs: the parody was contained with in a magazine and the "goods" the signs advertised were fictitious.

In summary, the non-infringing uses covered in this part are uses that involve: (1) common English Words (which happen to be registered as trade marks) in literary titles; (2) signs in literary titles when a trade mark owner or its goods is the subject matter of the book; (3) signs contained in complaint web sites to identify the subject of the discussion, and (4) signs used in satires or parodies.

57 See also News Group Newspapers Ltd v The Rocket Record Company Ltd [1981] FSR 89, 102 (HC) [News Group] where albeit in interlocutory proceedings Slade J found that the song title "Page Three" which was a direct reference to infamous page three of the Sun newspaper, was arguably not an infringement of the Sun's trade mark PAGE THREE. There had been no use in the trade mark sense: "I think [the plaintiff's counsel] would regard, and correctly regard, the name "Page Three" as being merely descriptive of the subject-matter of the song."

58 Spence, above n 56, 598-599; See generally Clark v Associated Newspapers Ltd [1998] 1 All ER 959, 967 968 (for parody under passing off); and News Group, above n 57, $103-105$.

59 Anheuser-Busch Inc v Balducci Publications (1993) 814 F Supp 791 (ED Mo).

60 Anheuser-Busch Inc v Balducci Publications (1993) 814 F Supp 791, 797 (ED Mo). However, on ap peal the defendant was found to have caused confusion, therefore, trade mark infringement was found: Anheuser-Busch Inc v Balducci Publications (1994) 28 F 3d 769 (8th Cir) [Anheuser-Busch]. 


\section{DILUTION}

Just as trade mark law varies from jurisdiction to jurisdiction, dilution itself varies in each jurisdiction. The theory of dilution will be discussed in this part, with Part IV dealing with the finer points of dilution under the Australian Proposal.

Dilution attributes a third function to trade marks, namely the advertising function. ${ }^{61}$ Therefore, dilution concerns another function of trade mark law, over and above the origin and quality functions protected under the Trade Marks Act 1953. The advertising function recognises trade marks as the vehicle through which the trade mark owner sells its goods. Thus the success of a certain good often does not depend on the intrinsic qualities of the good itself, but upon the advertising associated with the trade mark. ${ }^{62}$ Dilution protects the trade mark's selling power. For example, both $\mathrm{X}$ and $\mathrm{Y}$ have trade marks registered in class 32 in respect of beer. Y's trade mark is extremely well known and it signifies beer in other channels of trade, therefore, it has a selling power, a commercial magnetism, which dilution will protect regardless that the trade mark is registered only in class 32. X, on the other hand, has just begun to sell beer, and the trade mark is unknown in other channels of trade. Because X's trade mark has no selling power dilution will not protect X's trade mark against dilution. ${ }^{63}$

Although this article is concerned only with the effects of the tarnishment limb, some explanation of blurring is required. Schechter described the latter as the "gradual whittling away or dispersion of the identity and hold upon the public mind of the mark or name by its use on noncompeting products". ${ }^{64}$ Therefore, if an unauthorized person began to use Y's trade mark over handbags and shoes and there was a danger that Y's trade mark would come in time

61 Frank I Schechter "The Rational Basis of Trademark Protection" (1927) 40 Harv L Rev 813, 818.

62 See, for example, Westchester Media Co LP v PRL USA Holdings Inc (1999) L 12333, 5 - 6 (SD Tex) ("from its inception, Polo Ralph Lauren had initiated and vigorously pursued, an advertising theme which it has deemed "aspirational" ... that through this "aspirational" style of advertising, it has consistently invoked "lifestyle images" that resonate with elegance, luxury, and distinctively American imagery.") This despite Polo Ralph Lauren clothes being manufactured in third world countries in third world conditions: <http://www.summersault.com/ agj/clr/alerts/saipanexposetranscript.html> (last accessed 12 October 2000).

63 The level of protection given to X's trade mark will be the same as it currently enjoys under the Trade Marks Act 1953.

64 Schechter, above n 61,825 . Schechter did not deal in any way with tarnishment, this development was made by those who followed him, see for example, B W Pattishall "Dilution: Trademark Infringement or Will-O-the Wisp" (1964) Harv L Rev 520, 525 - 526. 
to mean not simply beer, but, beer, handbags and shoes, dilution by blurring would be found. ${ }^{65} \mathrm{Y}$ would be able to prevent the use of its trade mark over handbags and shoes. The difference been infringement under the Trade Marks Act 1953 (traditional trade mark law) and dilution by blurring is clear. Under traditional trade mark law Y would be unable to prevent the use of its trade mark over hand bags and shoes because the sign is being used over dissimilar goods. Of course, $\mathrm{Y}$ is not completely without protection under the general law. Passing off and the Fair Trading Act 1986 act as supplementary causes of action to the Trade Marks Act 1953. Neither cause of action is restricted by the requirement that the use must be on similar goods. ${ }^{66}$ McGechan J in Taylor Bros Ltd $v$ Taylor Group Ltd ${ }^{67}$ recognised that passing off provided protection against dilution, ${ }^{68}$ however both passing off and the Fair Trading Act 1986 are limited by their requirement to show likelihood of confusion. ${ }^{69}$ Dilution, on the other hand, is not limited by any such requirement: ${ }^{70} \mathrm{Y}$ does not need to show people seeing the shoes and handbags thought that $\mathrm{Y}$ was associated in some way with those goods. With the non-infringing uses, the signs were not being attached to other goods in order to sell the goods,

65 Whether or not a trade mark has actually suffered harm through dilution is arguable. Kenneth L Port "The Unnatural Expansion of Trademark Rights: Is a Federal Dilution Statute Necessary?" (1995) 85 TMR 525, 538: "[i]f it had, we should be able to point to a specific trademark that was worth $\mathrm{X}$ before entry of the newcomer but worth $\mathrm{X}$ minus $\mathrm{Y}$ after the entry of a non-competing and diluting newcomer." But this has not occurred. See also Y Pickering Trade Marks in Theory and Practice (Hart Publishing, Oxford, 1998)

66 The lack of a common field of activity is no longer fatal to a claim of passing off: see Taylor Bros Ltd v Taylor Group Ltd [1988] 2 NZLR 1, 37 - 38 (CA) where Lego System Aktieselskab v Lego M Lemelstrich Ltd [1983] FSR 155 (HC) was cautiously approved (plastic toy bricks and garden sprinklers).

67 Taylor Bros, above n 66, 15-16 (HC) per McGechan J.

68 Taylor Bros, above n 67, 15 - 16, affirmed by the Court of Appeal 37 - 38; see also Brown and Grant, above $\mathrm{n} 12$, para 3.13 (where passing off is treated as a non statutory form of dilution).

69 Fair Trading Act 1986, ss 9, 10, 11 and 13; see also Glengarry, above n 6, 266. Taylor Bros, above n 66, 22. Wineworths Group Ltd v Comite Interprofessionel du vin de Champagne [1992] 2 NZLR 327, 341 (CA) per Gault J (the essential element of passing off is "actual or likely misrepresentation or deception."). Passing off may, in time, lose this requirement: see Andrew Murray "A Distinct Lack of Goodwill" (1997) EIPR 345 (who believes the time has already come) and see generally Hazel Carty "Dilution and Passing Off: Cause for Concern" (1996) 112 LQR 632. Contrast W R Cornish Intellectual Property: Patents, Copyright, Trade Marks and Allied Rights (4 ed, Sweet \& Maxwell, London, 1999) para 17-101 (the over extension of passing off has only occurred in exceptional circumstances).

70 See for example, s 120(5) of the Australian Proposal which provides that dilution will occur "regardless of ... whether these actions give rise to a likelihood of confusion or deception ..." 
for example, a range of books was not published under the "Mother Care" sign, what was being sold $w$ as the expression itself.

On the other hand, tarnishment occurs when the use of a sign results in the "blackening or downgrading of the affirmative associations which the mark has come to convey". ${ }^{71}$ Because the protection of the affirmative associations is paramount, any use of a sign that damages or threatens to damage those associations will dilute the trade mark, regardless of whether confusion was caused. The definition of tarnishment is vague and extremely wide, however, as a leading proponent of dilution conceded, dilution has "no logical boundaries", ${ }^{72}$ and the use of a sign by an unauthorised person could make people think less of the trade mark and those things that it signifies.

The non-infringing uses have the potential to make people think unflattering thoughts about the trade mark owner or its goods. Mothercare published books that did not address all the issues involved in bringing up children, and it was simply attempting to push its products onto unsuspecting parents. The members of the rock group Wet Wet Wet were not as wholesome in real life as they had been made out to be. Bally's treatment of its customers was less than satisfactory. Parents may think twice about allowing their daughters to play with BARBIE dolls. People may be reminded of the effects of oil contamination upon the environment the next time they see the trade marks MICHELOB DRY, and ONE TASTE AND YOU'LL DRINK IT DRY.

In summary, dilution extends the ambit of trade mark protection by removing restrictions that the Trade Marks Act 1953 places on trade mark owners' rights. Does the Australian Proposal, therefore, place any limits on tarnishment's effects on the non-infringing uses?

71 Tony Martino Trademark Dilution (Clarendon Press, Oxford, 1996) 60. See also Deere \& Co v MTD Products Inc (1994) 41 F 3d 39, 43 (2nd Cir) (tarnishment occurs when a trade mark "is portrayed in an unwholesome or unsavory context likely to invoke unflattering thoughts about the owner's product).

72 Pattishall, above n 64, 529. 


\section{THE AUSTRALIAN PROPOSAL}

The Australian Proposal is a hybrid of the Trade Marks Act 1994 (UK) ${ }^{73}$ the United States' Trademark Act of 1946 (the Lanham Act), ${ }^{74}$ and the Trade Marks Act 1995 (Cth). ${ }^{75}$ The inclusion of aspects from the Lanham Act clarifies a number of issues left unanswered by the Trade Marks Act 1994 (UK). ${ }^{76}$

\section{A The Infringement Provision of the Australian Proposal}

Section 120 of the Australian Proposal provides that: ${ }^{77}$

73 Trade Marks Act 1994 (UK), s 10(3) A person infringes a registered trade mark if they use in the course of trade a sign which - (a) is identical with or similar to the trade mark, and (b) is used in relation to goods or services which are not similar to those for which the trade mark is registered, where the trade mark has a reputation in the United Kingdom and the use of the sign, being without due cause, takes unfair advantage of, or is detrimental to, the distinctive character or the repute of the trade mark.

74 Pub L No 104-98, 109 Stat 985 (codified at 15 USCS $\S 1125(\mathrm{c})$ and $\S 1127$ (2000)). Dilution is defined in $\S$ 1127 as "the lessening of the capacity of a famous mark to identify and distinguish the goods ... regardless of the presence of absence of ... competition between the owner of the famous mark and other parties, or ... likelihood of confusion, mistake or deception".

75 The Australian Proposal was designed to amend the Trade Marks Act 1995 (Cth).

76 (1) Is non trade mark use caught by the Trade Marks Act 1994 (UK)? Lord Strathclyde rejected an amendment proposed to ensure only trade mark use was caught, stating that the Trade Marks Bill, Public Bill Committee (which became the Trade Marks Act 1994 (UK)) only applied to the trade mark use of signs: (24 February 1994) 552 HL Hansard col 733. However, Jacob J in British Sugar Plc v James Robertsons \& Sons [1996] RPC 281 (HC) [British Sugar] found no such requirement. Other contentious issues are (2) is confusion a requirement? The High Court initially in BASF Plc v CEP (UK) Plc (26 October 1995) unreported, High Court per Knox J and Baywatch Production Co Inc v Home Video Channel [1997] FSR 22 (HC) thought it was, but subsequent cases have cast doubt on this: see, for example, One in a Million Ltd, above n 17, 499; British Sugar, 295. (3) What trade marks are in fact protected? See Martino, above n 71, 93 - 103. (4) Does infringement occur simply when unfair advantage of the distinctive character or repute of the trade mark has taken place? See Premier Brands UK Ltd v Typhoon Europe Ltd (21 January 2000) unreported, High Court, Chancery Division per Neuberger J [Premier Brands]: the exploitation of the good reputation of another's goods in order to enhance one's promotional efforts amounts to unfair advantage. Contrast Re CA Sheimer's Trade Mark App (No 2) [2000] RPC 484, 505 (Trade Mark Registry) detriment is also a requirement.

77 This "section" number (along with s 122) were both used by Ricketson, as the Australian Proposal was designed to amend the Trade Marks Act 1995 (Cth). 
(3) A person infringes a registered trade mark if the person uses a sign that is identical or similar to the trade mark in relation to any goods ... where the trade mark is well known within Australia and the result of such use is to dilute the distinctive character or reputation of the mark.

(4) In determining whether a registered trade mark is well known within Australia for the purposes of subsection (3), one must take account of, but not be confined to, the following factors:

(a) the degree of inherent or acquired distinctiveness of the mark;

(b) the duration and extent of use of the mark in connection with the goods ... with which the mark is used;

(c) the duration and extent of use of the mark in connection with any other goods ...;

(d) the channels of trade for the goods ... with which the owner's mark is used;

(e) the duration and extent of advertising and publicity of the mark and the extent to which the mark is known within the relevant sector of the public;

(f) the degree of recognition of the mark in the trading areas and channels of trade used by the mark's owner and the person against whom the injunction is sought;

(g) the nature and extent of use of the identical or similar marks by third parties; and

(h) the extent to which the trade mark is known within the Australian community or within a part of that community, as a result of the promotion of the mark that has occurred whether within or outside Australia or for any other reason.

(5) For the purposes of subsection (3), to 'dilute the distinctive character or reputation' of a registered trade mark that is well known in Australia means actions of a person that:

(a) lessen the capacity of the trade mark to distinguish goods...; or

(b) diminish the general reputation of the trade mark within the Australian community or a section of that community;

(c) regardless of whether the registered owner of the mark and that person are in competition with each other or whether these actions give rise to a likelihood of confusion or deception on the part of the relevant public.

(6) Without limiting the generality of actions which have the consequences referred to in paragraphs (a) and (b) of subsection (3), these include the following: 
(a) acts which place the mark in an inappropriate or damaging context or hold out the mark as having inappropriate associations;

(b) acts which hold the mark out to inappropriate ridicule or contempt;

Once the requirements in section 120(4)(a)-(h) are satisfied, protection against dilution extends to use over any goods (not simply identical or similar goods) regardless of whether confusion or deception has occurred. In addition, there is no requirement that the sign must be used as a trade mark or in a trade mark sense before infringement can be found. ${ }^{78}$

It is conceded, for the purposes of this article, that: (1) the signs in the non-infringing uses identified in Part II are identical or similar, and (2) the trade marks in question would be found to be well known under the non-exhaustive factors in section 120(4)(a)-(h). A detailed examination of these factors is beyond the scope of this article; however, in any action for dilution a trade mark owner must satisfy both (1) and (2).

\section{In relation to any goods}

The construction of the term "in relation to goods" will control the effect of dilution under the Australian Proposal on the non-infringing uses. Two constructions are possible. First, the term "in relation to goods" was used in the Trade Marks Act 1955 (Cth) where its construction was that a sign must be used to "refer to, or designate, such goods". ${ }^{79}$ Section 7 of the Trade Marks Act 1995 (Cth) defines "in relation to goods" as meaning "use upon or in physical or other relation to the goods". ${ }^{80}$ With the removal of "use as a trade mark", the term "in relation to any goods" will cover all uses of a sign upon goods or the use of a sign to refer to goods, for example, in advertising. The literary titles and the satirical song about BARBIE would therefore be caught. The use of a sign on a complaint web site where no goods were being sold or services offered, would appear not to be caught, as there is no use of a sign in relation to any goods. Nor would the use of a sign in goods, for example, a mock advertisement in a

78 "Use in a trade mark sense" was never included in Australian trade mark legislation, see for example: The Shell Co of Australia Ltd v Esso Standard Oil (Australia Ltd) (1963) 109 CLR 407, 424 per Kitto J.

79 S Ricketson The Law of Intellectual Property (Law Book Company, North Ryde (NSW), 1984) para 36.20 [The Law of Intellectual Property] referring to s 62(1) of the Trade Marks Act 1955 (Cth) citing Aristoc v Rysta Ltd (1943) 62 RPC 65 (HL).

80 Trade Marks Act 1995 (Cth), s 7 currently defines "use as a trade mark in relation to goods". It would appear that s 7 would have to be amended if the Australian Proposal was adopted in Australia. 
magazine come within this term, because it did not refer to, describe or designate the magazine or any other goods. ${ }^{81}$ The goods it was advertising were fictitious, and the sign was being used within goods, not upon goods.

Second, the term also appears in the Trade Marks Act 1994 (UK) ${ }^{82}$ and the English Court of Appeal in British Telecommunications Plc v One in a Million Ltd ${ }^{83}$ took a different view of the term. The defendant, a cyber squatter, had registered numerous domain names including "marksandspencer.com" and "britishtelecom.co.uk". The plaintiffs sought a mandatory injunction to have the domain names assigned to them. Aldous LJ found trade mark infringement had occurred under section 10(3) of the Trade Marks Act 1994 (UK) despite no web sites being operated under the above names. ${ }^{84}$ The signs were used in relation to the services provided by the defendant who traded in domain names. According to the English Court of Appeal, trade mark infringement occurs through the mere use of a sign in connection with goods or services, no matter how tenuous the connection. Thus the non-infringing uses would be caught. The defendant in Bally Total Fitness Holding Corp v Faber was a web page designer, it is arguable that the web page was a demonstration of his abilities, therefore, it was being used in connection with services.

Notwithstanding that, Ricketson did not refer to British Telecommunications Plc $v$ One in a Million Ltd, subscribing to the theory of dilution that results from trade marks law's objective being the prevention of damage to the trade mark. Ricketson was clear that the infringement provision catches any use of an identical or similar sign, unless the use comes with in an

81 See also the Trade Marks Act 1994 (UK), s 10(4) a person uses a sign if "in particular" he or she: (a) affixes it to goods or the packaging thereof; (b) offers or exposes goods for sale, puts them on the market or stocks them for those purposes under the sign, or offers or supplies services under the sign; (c) imports or exports goods under the sign; or (d) uses the sign on business paper or in advertising.

82 The wording of s 10(3) of the Trade Marks Act 1953 is "in relation to goods...", but the omission of "any" is not relevant as s 10(3) only applies to dissimilar goods, see above n 73, whereas s 120(3) makes not such distinction, hence the use of "any".

83 One in a Amillion, above n 17.

84 Contrast British Sugar, above n 76, 293 where Jacob J in commenting on Bravado Merchandising, above $\mathrm{n}$ 36 , took a very restrictive view of the term "in relation to goods" stating that: "One would have thought that Wet Wet Wet was used in the title simply to refer to the pop group. So it was not being used in relation to goods covered by the registration ... or to similar goods... Whilst added matter or other surrounding circumstances is irrelevant to the question of confusion, it must be relevant to decide in relation to what goods ... the sign is being used." 
exception. ${ }^{85}$ The width on the prohibition against use can be seen in the defence for the use of a sign "in the course of reporting news". ${ }^{86}$ If trade mark infringement can occur in the absence of confusion or deception, through the mere use of a sign upon goods, logically no distinction should be made if the sign appears within the goods. The "damage" to the trade mark owner is the same. Moreover, the potential harm from a complaint web site, accessible throughout the world, is far greater than the mere use of a sign upon or within a good. However, due to the use of the term "in relation to goods" some use in connection with goods or services is necessary. While the defendant's use of signs in Anheuser-Busch Inc v Balducci Publications would be a use in relation to goods, the use of a sign on a web page that had no connection with any goods or services would not be caught under the infringement provision.

\section{Dilution of the distinctive character or reputation of the mark}

The lessening of the "capacity of the trade mark to distinguish goods" deals with blurring $;{ }^{87}$ tarnishment is derived from the second part of the definition of "'dilut[ion] of the distinctive character or reputation' of a registered trade mark..." under section 120(5). ${ }^{88}$ Section 120(5)(b) provides that tarnishment will occur when the "general reputation of the trade mark within the Australian community or a section of that community" is diminished. Without limiting these words, the Australian Proposal deems that the general reputation is diminished if acts are done that: (1) place the mark in an inappropriate or damaging context or hold out the mark in in appropriate or damaging associations, ${ }^{89}$ or (2) hold the mark out to in appropriate ridicule or contempt. ${ }^{90}$

85 Ricketson, above n 5, 157.

86 Section 122(1)(e) of the Australian Proposal.

87 See above n 65 and accompanying text.

88 Ricketson, above n 5, 157 - 158; "[I]t could have been assumed that both blurring and tarnishment were covered by subsection (3)(a) and (b) [of section 120 of the Australian Proposal], but subsection (6) put it beyond question that all derogatory actions in relation to a well known mark were covered..." Section 120(5)(c) of the Australian Proposal is not reproduced as this paragraph appears to be targeting use by direct competitors, such as in Johnson \& Johnson Australia Pty Ltd v Sterling Pharmaceuticals Pty Ltd (1991) 101 ALR 700 (FCA). See also Ricketson, above n 5, 149.

89 Section 120(6)(a) of the Australian Proposal.

90 Section 120(6)(b) of the Australian Proposal. 
Not all associations, therefore, are inappropriate. The approach of the courts in the United States is that if the use of a sign is unlikely to make people think ill of the trade mark owner or its goods then tarnishment has not occurred. In Hormel Foods Corp v Jim Henson Products Inc ${ }^{91}$ the trade mark owner of SPAM, objected to the use of "Spa'am" as a name for a wild boar in the Muppets. The court found that after considerable negative publicity about the ingredients of SPAM, the trade mark owner should be pleased its product was being associated with a healthy pig. ${ }^{92}$ The court was clear that dilution should not prevent all uses of a trade mark that the trade mark owner prefers not to be made. ${ }^{93}$ Similarly, if the trade mark owner placed itself or its goods in an inappropriate context, it cannot deny the ability of others to point out this association..$^{94}$

Whether or not tarnishment will catch the non-infringing uses under the above approach will depend on the facts of each case. A true account of rock stars' lives, and a corporation's treatment of its customers detailed on the Internet would not be caught. On the other hand, the remaining non-infringing uses may well be found to be tarnishing, for example in AnheuserBusch Inc v Balducci Publications ${ }^{95}$ the court found that the trade mark had been tarnished. ${ }^{96}$ The parody connecting trade marks with oil contamination had placed the trade marks in an inappropriate and damaging context. Whether a New Zealand court would apply the same defence is not certain; damage to the reputation may be sufficient, indeed with the advent of the Internet; one person's bad experience could be magnified out of all proportion. Therefore, it cannot be said with any degree of certainty that all the non-infringing uses will not be caught by the infringement provision of the Australian Proposal. If those uses are caught, will the Australian Proposal provide defences to those uses?

91 Hormel Foods Corp v Jim Henson Products Inc (1996) 73 F 3 d 497 (2nd Cir) [Hormel].

92 Hormel, above n 91, 507: "countless jokes have been played off the public's unfounded suspicion that SPAM is a product of less than savory ingredients".

93

Hormel, above n 91, 508

94 See Stop the Olympic Prison v United States Olympic Committee (1980) 489 F Supp 1112 (SD NY) where an objection was made to a plan to convert an Olympic village into a prison.

95 Anheuser-Busch, above n 60.

96 Anheuser-Busch, above n 60, 778. Contrast Martino, above n 71, who only referred to the District Court decision of Anheuser-Busch Inc v Balducci Publications (1993) 814 F Supp 791 (8th Cir) which was overturned on appeal. 


\section{B Defences to Infringement}

Section 122 provides a number of defences; each defence relevant to this article will be looked at in turn. ${ }^{97}$

\section{Use in the course of trade}

Under section 122(1)(a) a sign is not infringed if a person uses a sign otherwise than in the course of trade. "In the course of trade" is not defined in the Act, but, it was a prerequisite of infringement under the Trade Marks Act 1955 (Cth). ${ }^{98}$ The term was interpreted extremely broadly under that Act as any dealing with goods up until the time they reached the hands of consumers. ${ }^{99}$ The term is also used in the Trade Marks Act 1994 (UK) and while it is not defined, trade is defined in section 103(1) including any "business or profession." As all the non-infringing uses of signs occurred through people or companies engaging in business, the signs would have been used in the course of trade. However, no matter how wide a view the courts take of the term "in relation to goods", it is submitted that a purely personal complaint web site would gain the protection of this defence.

\section{Descriptive use}

Section 120(1)(b) provides a defence to a person who "uses a sign in good faith to indicate the kind, quality, quantity, intended purpose (including as accessories or spare parts), value, geographical origin, or some other characteristic of goods ... or the time of production of the goods..." The defendant in Mothercare UK Ltd $v$ Penguin Books Ltd, ${ }^{100}$ who had used the descriptive title "Mother Care/Other Care", without knowledge of the plaintiff's trade mark, would be granted an exception. Common English words were innocently used to describe goods. Similarly, Lord McCluskey in Bravado Merchandising Ltd v Mainstream Publishing Ltd ${ }^{101}$

97 Comparative advertising is also provided as an exception: Section 122(1)(d) of the Australian Proposal, "the person makes fair use of the trade mark for the purposes of comparative commercial advertising or promotion to identify the competing goods ... of the registered ow ner". However, such use of a sign is beyond the scope of this article as the non-infringing uses do not involve comparative advertising. Comparative advertising is not currently permitted in New Zealand except in narrow circumstances in respect to Part B marks: Trade Marks Act 1953 s 9(2), see generally PC Direct, above n 44.

98 Trade Marks Act 1955 (Cth), s 62(1).

99 The Law of Intellectual Property, above n 79, para 36.19.

100 Mothercare, above n 29.

101 Bravado Merchandising, above n 36. 
was clear that the equivalent section in the Trade Marks Act 1994 (UK), ${ }^{102}$ provided a defence to the defendant's use of a sign in a book entitled "A Sweet Little Mystery - Wet Wet Wet - The Inside Story". To Lord McCluskey the defendant was describing the main characteristic of the book, the title indicated that the book concerned the rock group. ${ }^{103}$ This defence should also apply to the complaint web site in Bally Total Fitness Holding Corp v Faber ${ }^{104}$ - the sign was being used to identify the subject of the discussion.

Unlike the Trade Marks Act 1953 where the above descriptive uses would not result in trade mark infringement, such uses are now prima facie an infringement, but they are provided with an "exception". Would an unauthorised biography which portrayed the subject in a critical manner, which the trade mark owner objected to, and the biographer knew of the objection, be use in good faith?

\section{Fair parody or satire}

Finally, under section 120(1)(f) the use of a trade mark by way of fair parody or satire will not result in infringement. The United Kingdom has avoided dealing with parody altogether, creating considerable concern in that jurisdiction. ${ }^{105}$ Unfortunately, the Australian Proposal does nothing to address this concern. The purpose of parody and satire is to hold people or things out to inappropriate ridicule or contempt; ${ }^{106}$ however, acts that hold out a trade mark to inappropriate ridicule or contempt are caught by the infringement provision of the Australian

102 Trade Marks Act 1994 (UK), s 11(2): "A registered trade mark is not infringed by - ... (b) the use of indications concerning the kind, quality, quantity, intended purpose, value, geographical origin, the time of production of goods ... or other characteristics of goods ... or (c) the use of the trade mark where it is necessary to indicate the intended purpose of a product ... (in particular, as accessories or spare parts), provided the use is in accordance with honest practices in industrial or commercial matters."

103 Bravado Merchandising, above n 36, 216. Contrast, British Sugar, above n 76, 293 where Jacob J thought that the use was not caught by s 10 of the Trade Marks Act 1994 (UK).

104 Bally, above n 48.

105 See generally Spence, above n 56 .

106 The New Shorter Oxford Dictionary (4 ed, Clarendon Press, Oxford, England, 1993): Parody is defined as "prose, verse or ... other artistic composition in which the characteristic themes and the style of the particular work ... are ... exaggerated or applied to an inappropriate subject, esp. for the purposes of ridicule." Satire is similarly defined as "[a] work of composition in prose ... which ... exposes prevailing vices or follies or ridicules an individual...." 
Proposal. Therefore, as Ricketson observed, there is no such thing as fair parody or satire. ${ }^{107}$ What then does "fair" parody or satire mean? Ricketson's examples of fair parody occurred in situations where one trader had used the trade marks of another trader humorously in order to advertise their own goods. He argued that the courts in Australia had failed to take the parody in to account when determining whether infringement had occurred. ${ }^{108}$ Indeed the defence for "fair parody" appears to supplement the defence of comparative advertising available to rival traders - use of a sign is acceptable so long as the gloves are not taken off. The satire of BARBIE and the parody in Anheuser-Busch Inc v Balducci Publications (if the latter was caught by the infringement provision) represent the savage type of parodies, which would not enjoy the benefit of this defence.

\section{TRADE MARKS AS PROPERTY}

\section{A The Propertisation of Trade Marks}

Trade marks have long been considered to be a form of property, ${ }^{109}$ however, the property right granted by traditional trade mark law was limited. ${ }^{110}$ Dilution will greatly increase the rights attributed to some trade marks, making a trade mark a stronger property right in the hands of trade mark owners. ${ }^{111}$ Whereas traditional trade mark law protected the trade mark owner's business, dilution now protects the trade mark itself, ${ }^{112}$ or to be more accurate, the investment expended in creating the trade mark's selling power. The latter can be seen in Glengarry's argument in favour of dilution. The trade mark owner has made a substantial

107 Ricketson, above n 5, 159

108 One example given was AGL Sydney Ltd v Shortland County Council (1989) 17 IPR 99 (FCA) (albeit it dealt with copyright infringement). A television advertisement which encouraged people to install gas hot water systems was parodied by the council who wanted electric hot water systems to be used, and no allowance was made for the fact that no person seeing the defendant's advertisement would be confused.

109 Trade Marks Act 1953, s 80(1) "equities in respect of a trade mark may be enforced in like manner as in respect of any other personal property".

110 See above Part II

111 See, for example, a new provision in the Trade Marks Act 1994 (UK), s 22 "A registered trade mark is personal property..."; Premier Brands, above n 76: trade mark owners now have "a type of protection not so far afforded to them under English law"; Pickering, above n 65, 117 - 118 .

112 Milton W Handler "Are the State Antidilution Laws Compatible with the National Protection of Trademarks?" (1998) 88 TMR 419, 423. 
investment in creating an image for its brand, and it is unfair that others can take the benefit of that investment without compensating the trade mark owner. Misappropriation ought not to be allowed. ${ }^{113}$

A number of arguments can be raised against the increase of property rights afforded to trade marks. First, the ability of others to take the ben efit of the trade mark owner's investment without compensating the trade mark owner does not explain the tarnishment limb. It is arguable that some of the non-infringing uses do increase the attractiveness of the goods upon which they are contained. For example, a biography of a well-known rock group will sell better than a biography of a rock group few people know about. But, signs are not always used to increase the attractiveness of goods. A complaint web site that simply points out the defects in the trade mark owner's goods is not appropriating the benefit of any investment. ${ }^{114}$ The trade mark owner's objection is not that an unauthorised person is making money from the trade mark owner's investment, the objection is to the critical portrayal of the trade mark. ${ }^{115}$

Second, it is arguable that a trade mark is valuable - the use of it upon goods, or in goods, increases the value of those goods - the trade mark owner should be able to exclude others from using the sign. The common law, however, has steadfastly refused to accept this argument; a thing will only be protected if it comes within one of the pre-existing heads of protection. ${ }^{116}$ While trade mark law is one of the heads of protection, dilution greatly extends this head of protection. ${ }^{117}$ Indeed the argument that because a thing has a value it ought to be

113 See Glengarry, above n 6, 267.

114 Susy Frankel "Unfair Competition Law - 'Over Protection Stifles the Very Creative Force it is Supposed to Nurture"' in C E F Rickett and G W Austin (eds) International Intellectual Property and the Common Law World (Hart Publishing, Oxford, 2000) 282.

115 See Mark A Lemley "The Modern Lanham Act and the Death of Common Sense" (1999) 108 Yale LJ $1687,1713$.

116 Yves St Laurent Parfums v Louden Cosmetics Ltd (1997) 39 IPR 11, 26 (HC). See also Cadbury-Schweppes Pty Ltd v Pub Squash Co Pty Ltd [1981] 1 All ER 213 (PC); Victoria Park Racing and Recreation Grounds Co Ltd v Taylor (1937) 58 CLR 479, 509 per Dixon J.

117 A question, that is beyond the scope of this paper is - if everything that is valuable is capable of being owned, at what point will a line be drawn between what is owned, and what is not owned? See for example, Lemley, above n 115, 1715. 
protected is a vicious circle: a thing only has a value if others are excluded from using it - if others are not excluded from using it, it has no value. ${ }^{118}$

Third, the economic justifications Glengarry provided in favour of New Zealand adopting the Australian Proposal are flawed when they are applied to the tarnishment limb of dilution. ${ }^{119}$ He argues that: (1) trade marks ought to be protected because consumers benefit through lower search costs, and (2) if trade marks are not protected there will be little incentive for a company to improve the quality of its goods. These arguments are easily refuted, in response to (1): no searching is involved with the goods in question; the consumer is not confused about what they are purchasing, if they are purchasing anything at all. In respect of (2), has Mattel, after the satire of BARBIE, stopped improving the quality of its BARBIE dolls? ${ }^{120}$ Both justifications are premised on the tradition of "protecting" a consumer, but the consumer is in no need of protection. Indeed proscribing tarnishment will harm the consumer ${ }^{121}$ if, for example, criticising the actual quality of goods can result in a trade mark owner improving the quality of its goods.

Finally, the granting of greater property rights to trade marks owners will result in trade mark owners enjoying better rights than those granted to the owner of real property - the benchmark of intellectual property rights. ${ }^{122}$ The owner of real property cannot regulate the actual speech directed at its property, only the place where the speech takes place. For example, in the United States the owner of a shopping centre can prevent people handing out leaflets, holding placards and other forms of protest, when those people are on the shopping

118 See, for example, Tot Toys Ltd v Mitchell [1993] 1 NZLR 325, 360 - 363 (HC) where Fisher J firmly rejected the existence of character-merchandising rights in New Zealand due to this circular argument. See also Felix S Cohen "Transcendental Nonsense and the Functional Approach" (1935) 35 Colum L Rev 809, 815 .

119 See Glengarry, above n 6, 267 citing William M Landes and Richard A Posner "The Economics of Trade Mark Law" (1988) 78 TMR 267, 270 and 279. Both economic justifications were for standard trade mark protection, not the increased protection provided by dilution.

120 Mattel, above n 54.

121 See for example, $L L$ Bean, above n 51, 34 where the court was critical of anti-dilution statutes being used by trade mark owners to shield themselves from criticism.

122 See for example William M Landes and Richard A Posner "Trademark Law: An Economic Perspective" (1987) $30 \mathrm{~J}$ Law \& Economics 265, 266 who begin their analysis of the economics of trade mark protection with the example of an owner of pasture being able to exclude others from grazing their cattle on it. 
centre's premises. Those rights do not extend to preventing someone carrying out the same activities if that person stands on another's property, or public property. ${ }^{123}$ The user of a sign, unlike the placard holder, cannot move to another place, all that can be altered is the speech itself.

\section{B The Effects of the New Property Right on Free Speech}

The expansion of the bundle of property rights afforded to a trade mark brings two competing interests into direct conflict. A trade mark owner, as a property owner, is entitled to have its property protected. On the other hand, section 14 of the New Zealand Bill of Rights Act 1990 ("Bill of Rights")confirms to the public the right of freedom of expression - the right of free speech. The court in Mattel Inc v MCA Records Inc was in no doubt that the satire of BARBIE involved freedom of speech issues: ${ }^{124}$

The central role which trademarks occupy in public discourse (a role eagerly encouraged by trade mark owners), makes them a natural target of parodists. Trademark parodies, even when offensive, do convey a message. The message may be simply that business and product images need not always be taken too seriously; a trade mark parody reminds us that we are free to laugh at the images and associations linked with the mark ... Denying parodists the opportunity to poke fun at symbols and names which have become woven into the fabric of our daily life, would constitute a serious curtailment of a protected form of expression.

Under the Trade Marks Act 1953 there is no conflict, the trade mark owner's right is confined within a small defined area, all that is left over belongs in the commons. ${ }^{125}$ However, notwithstanding the limited application of the Trade Marks Act 1953 on free speech, Elias J in PC Direct Ltd $v$ Best Buy Ltd ${ }^{126}$ found that comparative advertising raised free speech issues, in the form of section 14 of the Bill of Rights. The inability of people to be informed of information about different manufacturer's goods was seen by Elias $J$ as a limit on the ability of people to receive information, and as such her honour refused to grant an interlocutory injunction. With the greatest of respect to Elias J, section 14 of the Bill of Rights is, of course, subject to both

123 Lloyd Corp Ltd v Tanner (1972) 407 US 551.

124 Mattel, above n 54, 1155 - 1156, quoting LL Bean, above n 51, 34.

125 See generally, Patricia Loughlan "Protecting Culturally Significant Uses of Trade Marks (Without a First Amendment)" (2000) EIPR 328; Wendy J Gordon "A Property Right in Self-Expression: Equality and Individualism in the Natural Law of Intellectual Property" (1993) 102 Yale LJ 1533.

126 PC Direct, above n 44, 323. 
sections 4 and 5. The combination of both sections 4 and 5 makes it clear that a court can not "decline to apply any provision of [an] enactment - by reason only that the provision is inconsistent with any provision of this Bill of Rights". ${ }^{127}$ The final nail in the coffin for a comparative advertiser, which effectively removed the defence to the comparative advertiser, came in 1994 - after the enactment of the Bill of Rights. ${ }^{128}$ Parliament, therefore, deliberately granted trade mark owners greater rights. Elias J favouring section 14 of the Bill of Rights over the clear legislative intent of the Trade Marks Act 1953 in its current form speaks more for what her honour believes the law ought to be, not what it actually is. ${ }^{129}$

Leaving comparative advertising aside and returning to the "non infringing uses", if dilution is introduced along the lines of the Australian Proposal, which "right" is to prevail? There is no express provision that freedom of speech is not to be impinged by the new law. Mostert, writing in the United States, and arguing in favour of dilution, acknowledged that a limit must be placed on the scope of protection for trade marks. "[F]ree speech ... demands that the commercial magnetism or popularity values vested in the trade mark ... be used freely in the dissemination of news and information, the creation of a new work of art and symbolic speech." 130

Can section 14 of the Bill of Rights be used limit the scope of protection for trade marks? Notwithstanding Elias J's comments in PC Direct it is suggested that it cannot. The Bill of Rights is modeled on the Canadian Charter of Rights and Freedoms ("the Charter"). Compagnie Générale des Établissements Michelin - Michelin \& Cie v National Automobile, Aerospace,

127 New Zealand Bill of Rights Act 1990, s 5: "Subject to section 4 the rights and freedoms contained in this Bill of Rights are subject only to such reasonable limits prescribed by law as can be demonstrably justified in a free and democratic society." Section 4 provides that "No court shall, in relation to any enactment... (a) Hold any provision of the enactment to be impliedly repealed or revoked, or to be in any way invalid or ineffective; or (b) Decline to apply any provision of the enactment - by reason only that the provision is inconsistent with any provision of this Bill of Rights".

128 See for example, Frankel, above n 114, 277 who describes the removal of the statutory defence in relation to Part B marks (see above $\mathrm{n} 44$ ) as making the defence for a comparative advertiser redundant.

129 See Frankel, above n 114, 277 who noted the refusal of Elias J to grant an injunction as being "contrary to the legislative intent which extended the trade mark law to protect a trader from unfair competition by way of comparative advertising using trade marks. Elias J's refusal ... expresses the view that this strand of unfair competition law has gone too far."

130 Frederick W Mostert "The Parasitic Use of the Commercial Magnetism of a Trade Mark on NonCompeting Goods" (1986) EIPR 342, 347. 
Transportation and General Workers of Canada ${ }^{131}$ demonstrates the ranking of the rights clearly. The defendant argued that the Canadian Copyright Act of 1985 should be "read down" by the Charter. ${ }^{132}$ The court refused to accept this argument, stating that the Charter did "not confer... the right to use private property ... in the service of freedom of expression." 133 Indeed many courts in the United States have refused to apply the First Amendment, which unlike the New Zealand Bill of Rights Act 1990 is not subject to constraints, ${ }^{134}$ finding that property rights were paramount. ${ }^{135}$

In New Zealand, as it is clear that property rights prevail over freedom of speech, Parliament must act positively if free speech is not to be affected by dilution. ${ }^{136}$ Ricketson himself acknowledged the danger dilution posses to free speech, stating that "specific defences or exceptions to infringement" were required to maintain the balance between public and private interests. ${ }^{137}$ However, the "specific defences and exceptions" in the Australian Proposal have not achieved this balance. An example of the balancing of public and private interests in dilution legislation can be seen in the United States approach to dilution.

131 Compagnie Générale des Établissements Michelin - Michelin \& Cie v National Automobile, Aerospace, Transportation and General Workers of Canada [1997] 2 FC 306, 362 (Fed TD) [Michelin].

132 Canadian Charter of Rights and Freedomes Part I of the Constitution Act 1982 in Canada Act 1982 (UK) $\operatorname{sch} \mathrm{B}, \mathrm{cl} 11$.

133 Michelin, above $\mathrm{n} \mathrm{131,361-362} \mathrm{cited} \mathrm{in} \mathrm{Kotler} \mathrm{"Trade-mark} \mathrm{Parody,} \mathrm{Judicial} \mathrm{Confusion} \mathrm{and} \mathrm{the}$ Unlikelihood of Fair Use" (2000) 14 IPJ 217, 231. The Charter, s 1 provides that: "The ... Charter ... guarantees the rights and freedoms set out in it subject only to such reasonable limits prescribed by law as can be demonstrably justified in a free and democratic society." Section 33(1) "Parliament ... may expressly declare in an Act of Parliament ... that the Act or a provision thereof shall operate notwithstanding [the freedom of expression granted in] section 2 ... of this Charter."

134 New Zealand Bill of Rights Act 1990, s 5.

135 See for example Anheuser-Busch, above n 60, 778; Pillsbury Co v Milky Way Productions Inc (1981) 215 USPQ 124, 135 (ND Ga); Coca-Cola Co v Gemini Rising Inc (1972) 346 F Supp 1183 (ED NY).

136 See for example Jo Oliver "Copyright, Fair Dealing, and Freedom of Expression" (2000) NZULR 89 for the difficulties of attempting to raise a freedom of expression defence under the Copyright Act 1994.

137 Ricketson, above n 5, 139. 


\section{THE UNITED STATES EXPERIENCE}

The Lanham Act provides an express defence for non-commercial use of signs. ${ }^{138}$ Noncommercial expression, guarantees the right to freedom of speech as granted by the First Amendment. ${ }^{139}$ The non-commercial defence has been described as including, "parody, satire, and other forms of expression that are not a part of a commercial transaction."140 The latter part of this explanation is misleading; the fact that a good bearing a sign is sold does not mean that is part of a commercial transaction in the United States. For instance, the satire of BARBIE in Mattel Inc v MCA Records Inc was deemed to be non-commercial use. ${ }^{141}$ The fact that the use of a sign makes the goods more attractive is irrelevant. ${ }^{142}$ Non-commercial speech is simply when there is no use as a trade mark, the sign is not acting as an identification symbol for the source of the users' goods. ${ }^{143}$ In Mattel Inc v MCA Records Inc the use was of the sign "BARBIE" was for the purposes of satire, not to sell "knock-off" BARBIE products. ${ }^{144}$

The United States legislature has balanced the competing rights, with the right to freedom of speech being favoured. ${ }^{145}$ The importance of an express protection for non-commercial speech, the protection of free speech, cannot be understated. As one commentator in the United States observed, "the First Amendment stands (or should stand) as a bulwark against

138 Section 1125(c)(4)(b): "the following shall not be actionable under this [dilution] section... Non commercial use of a mark."

139 Bally, above n 48, 1167; Mattel, above n 54, 1155.

140 Mr Moorhead (12 December 1995) 141 Cong Rec H 14317.

141 Mattel, above n 54, 1155.

142 Mattel, above n 54, 1155 "Even if [the pop group] knew that parodying a popular product would attract favorable attention, this knowledge alone cannot erase their First Amendment interests in commenting on Barbie: if it did, then no unknown group could criticize popular products because the accusation of trying to gain attention would always exist." See also See Dr Seuss Enters LP v Penguin Books USA Inc (1996) 924 F Supp 1559, 1574 (SD Cal).

143 See generally, Robert C Denicola "Trademarks as Speech: Constitutional Implications of the Emerging Rationales for the Protection of Trade Symbols" [1982] Wisconsin L Rev 158;

144 Mattel, above n 54, 1155; see also Arlen W Langvardt "Trademark Rights and First Amendment Wrongs: Protecting the Former without Committing the Latter" (1993) 83 TMR 633, 645.

145 The balancing exercise was performed at the time the Constitution was drafted: Konigsberg $v$ State Bar (1961) 366 US 36, 61 per Black J, cited in Basil Markesinis "Judicial Style and Judicial Reasoning in England and Germany" (2000) 59 CLJ 294, 299. 
the increasingly common effort to use trade mark law to suppress speech". ${ }^{146}$ Under the Lanham Act, therefore, all the non-infringing uses would be protected, ${ }^{147}$ regardless of the level of damage that may be caused to the trade mark. ${ }^{148}$

Ricketson, when discussing the type of "appropriate" exceptions to dilution believed that dilution should not cover "non-commercial uses". ${ }^{149}$ The closest the Australian Proposal comes to providing a defence for non-commercial use is the defence for use, which is not in the course of trade. ${ }^{150}$ However, as we have seen this requirement did not operate to provide a defence for the non-infringing uses.

\section{CONCLUSION}

The Ministry of Commerce was correct in 1991 that dilution would introduce uncertainty into the law. ${ }^{151}$ With the Australian Proposal, there is no certainty as to exactly what uses of signs would be result in trade mark infringement. Contrary to the Ministry's assertions on the effect of dilution, trade mark owner's rights would be extended well beyond that already provided by passing off and the Fair Trading Act 1986 - infringement can occur in the absence of confusion. Notwithstanding Ricketson's understanding that dilution ought not to effect non-commercial use, the Australian Proposal fails to offer a defence for such use.

146 Lemley, above n 115, 1715.

147 (1) Infringement by literary titles: Twin Peaks Productions Inc v Publications International Ltd (1993) $996 \mathrm{~F}$ 2d 1366, 1379 (2nd Cir), the First Amendment grants the author a right to choose an appropriate nonconfusing title for its work. (2) Complaint web sites: Bally, above n 48. (3) Satire and parody: Mattel, above n 54 .

148 Mattel, above n 54, 1155: "even if the song did tarnish ... the Barbie mark, defendants' speech falls within the "noncommercial use of a mark."

149 Ricketson, above n 5, 139.

150 Section 122(1)(a) of the Australian Proposal.

151 The requirements of the Paris Convention for the Protection of Industrial Property of 1883, revised at Brussels (1900), Washington (1911), The Hague (1925), London (1934), Lisbon (1958) and Stockholm (1967) and the TRIPS Agreement, the World Trade Organisation Trade Related Aspects of Intellectual Property Rights, Annex 1c to the World Trade Organisation Agreement, Uruguay 1993 have not been dealt with in this article because of space constraints. Both Ricketson, above n 5, 143 and Glengarry, above $\mathrm{n}$, at 267 conceded that these international obligations did not proscribe dilution. In addition, the United States specifically excludes the non-infringing uses addressed in this article from its trade mark protection: see above Part VI. 
The economic justifications for the extension of trade mark owners' rights are not satisfactory. For example, the lack of protection against tarnishment will not increase consumers' search costs; the consumer knows exactly what they are dealing with. Moreover, despite harm not equaling an obligation under the common law, it is doubtful that the trade mark owner is actually suffering any harm at all. By "harm" the writer means harm, that occurs independently of the trade mark owners' actions. Trade mark owners should not be protected against the stark realities of the truth, or being made fun of. The paradox of protecting against tarnishment is that the stronger the trade mark is the more attractive a target it will be, but its strength means that its reputation will not suffer much, if at all. Furthermore, those trade marks which have yet to have a strong image built around them and are therefore susceptible to harm are specifically exclu ded from the protection of dilution. ${ }^{152}$

152 Section 120(4)(a)-(h) of the Australian Proposal. 